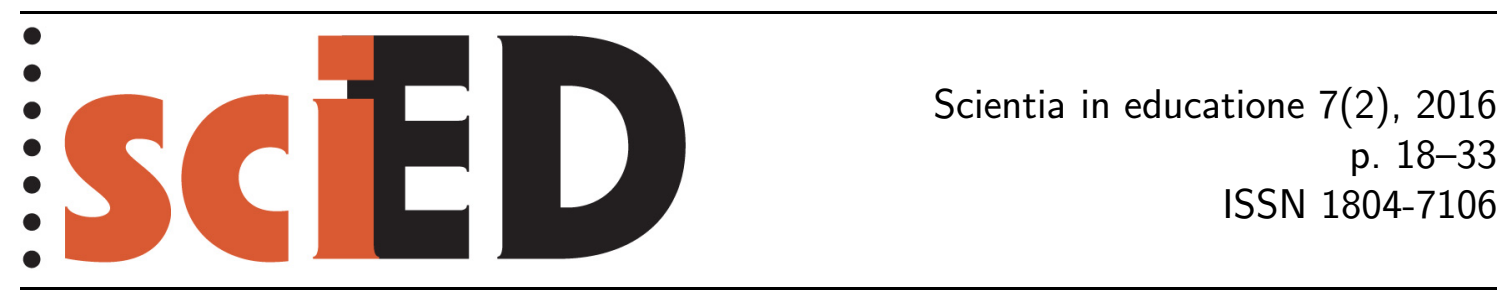

\title{
Metody sběru dat využivané didaktikou fyziky v mezinárodním prostředí
}

\author{
Vojtěch Žák
}

\begin{abstract}
Abstrakt
Strategickým cílem výzkumu, jehož součástí je tato přehledová studie, je reflektovat vývoj a současný stav didaktiky fyziky (physics education research, dále PER). Cílem této studie je podat přehled metod sběru dat, a podpořit tak diskuzi o metodách výzkumu využívaných $\mathrm{v}$ této oblasti. $\mathrm{K}$ řešení výzkumného problému byl použit kvalitativní přístup a za metodu sběru dat obsahová analýza výzkumných sdělení. Za zdroj těchto textů byla zvolena databáze SCOPUS, přičemž analýza se omezila na relevantní časopisecké články, které byly publikovány v letech 2010 až 2014 a které jsou psány anglicky. Celkem bylo analyzováno 146 článků. Jako metody sběru dat jsou využívány v oblasti PER dotazník, interview a didaktický (zejména konceptuální) test. Dále se uplatňuje analýza nejrůznějších dokumentů, pozorování, př́íp. další metody. Př́inosem pro další výzkum v oblasti PER, at na mezinárodní nebo lokální úrovni, může být fakt, že v mezinárodním prostředí existují standardizované výzkumné nástroje, zejména konceptuální testy a různé dotazníky. Protože tato studie abstrahuje do značné míry od fyzikálního obsahu, mohou být uvedená zjištění př́nosná i pro výzkumníky v oblasti science education research.
\end{abstract}

Klíčová slova: didaktika fyziky, výzkum fyzikálního vzdělávání, výzkumná metoda, metoda sběru dat.

\section{Data Collection Methods in Didactics of Physics in the International Environment}

\begin{abstract}
The strategic goal of the research, which also includes this systematic review, is to reflect the development and current situation in the field of physics education research (hereafter referred to as PER). The purpose of the review is to present an outline of data collection methods and to foster discussion about research methods used in this field. Qualitative approach was used to deal with the research problem, complemented by the content analysis of research studies as a data collection method. The SCOPUS database was chosen as a source of the analysed texts, yet the analysis was limited only to relevant journal articles, 146 in total, published in English between 2010 and 2014. The data collection methods used in PER include questionnaires, interviews, and achievement tests (which are predominantly conceptual). Furthermore, there are analyses of various documents, observations, or other methods. A benefit for further research in the field of PER, both on
\end{abstract}


the local or international level, may be the fact that standardised research methods are used in the international environment, particularly conceptual tests and questionnaires. This study abstracts away, to a certain extent, from the realm of physics. This is why the presented findings may be beneficial also for other researchers in the field of science education.

Key words: didactics of physics, physics education research, research method, data collection method.

\section{ÚVOD}

V posledních letech sílí v České republice snaha o reflexi didaktiky fyziky jako vědeckého oboru. Dokladem tohoto úsilí je několik studií, z nichž některé mají přehledový charakter (zejména Nezvalová, 2011; Dvořák, Kekule \& Žák, 2012, 2015), jiné se v rámci reflexe zaměřují úžeji (např. Žák, 2014, 2015). Česká didaktika fyziky není v tomto smyslu osamocená; reflexí procházejí také další oborové didaktiky (Stuchlíková \& Janík, 2011, 2015). Součástí práce výzkumníků v daném oboru by měla být systematická rešerše odborné literatury. Tato rešerše se většinou zaměřuje na téma problému, k jehož řešení chce výzkumník přispět. Domníváme se, že může být pro badatele v dané oblasti př́nosem seznámit se i s metodologií výzkumů, které se mnohdy jeho úzce vymezeného tématu př́mo netýkají, přesto ale mohou být inspirací pro jeho práci a zároveň mohou poskytnout určitý nadhled nad řešením často velmi úzce vyprofilované množiny výzkumných otázek.

Přesvědčení, že součástí reflexe určitého vědeckého oboru by měla být diskuze otázek spojených s metodologií daného oboru, není nové. Metodologie byla v české odborné didakticko-fyzikální literatuře systematicky diskutována již před desítkami let - uved’me např. dílo J. Fenclové (1982: s. 106-135). Nicméně se zdá, že chybí analýza metod sběru dat (a dalších otázek spojených s metodologií), které jsou využívány v současné době v mezinárodním prostředí v didakticko-fyzikálním výzkumu (physics education research, dále jen $\mathrm{PER}^{1}$ ), tedy nikoli jen v oblasti šiřeji pojatého výzkumu ve vzdělávání. Potřeba této analýzy, přehledu a nadhledu se jeví jako značná také $\mathrm{z}$ toho důvodu, že $\mathrm{v}$ disertačních pracích $\mathrm{z}$ didaktiky fyziky obhájených v posledních letech v Ceské republice byly identifikovány určité metodologické rezervy (Žák, 2015: s. 42-45). V mezinárodním prostředí již byly určité analýzy spojené s metodologií PER podniknuty; na používanou metodologii lze do jisté míry usoudit např. na základě přehledového díla Frasera et al. (2012). Tato publikace ale není strukturována podle použité metodologie a navíc spadá do oblasti šiřreji pojatého science education research.

Strategickým cílem výzkumu, jehož součástí je tato přehledová studie, je reflektovat vývoj a současný stav didaktiky fyziky, resp. PER. ${ }^{2}$ Cílem této studie je podat přehled metod sběru dat, a podpořit tak diskuzi o metodách výzkumu využívaných v oblasti didaktiky fyziky (PER) a obecněji v oblasti didaktik př́rodovědných oborů

\footnotetext{
${ }^{1} \mathrm{~V}$ rámci tohoto článku užíváme pojmy výzkum $v$ didaktice fyziky a physics education research jako synonyma. Podrobnější vymezení a souvislosti viz Dvořák et al. (2015: s. 126-131).

${ }^{2}$ Autor se tím snaží navázat na výzvu v jedné ze svých předchozích prací (Žák, 2014: s. 240).
} 
( science education research, SER). ${ }^{3}$ Snahou je podat plastický (byt' ne úplný) přehled metod sběru dat (včetně odkazů na konkrétní výzkumné nástroje), dát je do souvislosti s výzkumnými př́stupy a výzkumnými plány, a to nezávisle na výzkumných problémech, které jednotlivé práce řeší. $V$ tomto bodě by předkládaná analýza měla přesáhnout běžnou činnost výzkumníka, který v literatuře typicky vyhledává ty výzkumy, které se přímo týkají jím řešené výzkumné otázky. Snahou je propojit tato zjištění alespoň částečně s českým kontextem - konkrétně s domácími disertačními pracemi z didaktiky fyziky.

Jako výzkumný problém byla stanovena následující otázka:

- Které metody sběru dat jsou v mezinárodním prostředí v současné době v PER využívány?

Studie je určena především výzkumníkům v oblasti didaktiky fyziky, mezi nimi zejména začínajícím badatelům (studentům doktorského studia); má ale ambici zasáhnout širší publikum - výzkumníky v oblasti didaktik dalších př́írodovědných oborů. Text je strukturován tak, že po části věnované metodologii tohoto výzkumu (kapitola 1) následuje část s výsledky provedené analýzy (kapitola 2). V rámci ní jsou nejprve uvedeny časopisy, které se ukazují jako relevantní zdroje textů určených k analýze (podkapitola 2.1), následuje stěžejní část s přehledem metod sběru dat identifikovaných v PER (2.2) a dále je uvedena orientace výzkumných přístupů a výzkumné plány (2.3). V závěru a diskuzi (kapitola 3 ) je zvláštní pozornost věnována porovnání s metodologií uplatňovanou v českých disertačních pracích z didaktiky fyziky. V př́lloze je uveden seznam časopisů, ze kterých pocházejí analyzovaná výzkumná sdělení.

\section{Metodologie}

Vzhledem ke stanovenému výzkumnému problému byl k řešení zvolen v zásadě kvalitativní př́istup a za metodu sběru dat obsahová analýza textů (výzkumných sdělení). Kvalitativní přístup byl zvolen zejména z toho důvodu, že jde v první řadě o identifikaci výzkumných metod, zatímco četnost jejich používání byla sledována spíše okrajově.

Na používání různých výzkumných přístupů a metod ve fyzikálním vzdělávání je možné usuzovat z nejrůznějších zdrojů. Mezi ně jistě patří výzkumné články v časopisech, odborné knihy, sborníky z konferencí a závěrečné zprávy výzkumných projektů. Vzhledem k množství konferencí a také projektů v rámci PER (a jejich dohledatelnosti) je zřejmé, že je nutné omezit se na určitou užší, přesto ale relevantní skupinu výzkumů a souvisejících textů, na základě kterých je možné usuzovat na metodologii PER využívanou v současné době v mezinárodním prostředí.

Za vhodnou (nikoli jedině možnou) skupinu těchto textů byly zvoleny časopisecké články spadající do oblasti PER a za zdroj těchto článků byla zvolena databáze SCOPUS ${ }^{4}$. Výběr byl dále omezen na články publikované během nedávného pětiletého období - v letech 2010 až 2014. Jako hlavní klíčové slovo (na příslušné webové

\footnotetext{
${ }^{3}$ Některé články (a příslušné výzkumy) analyzované v rámci této studie spadají kromě PER také do oblasti SER. Zjednodušeně lze říci, že pokud v nalezených článcích, které spadají do SER, byly nalezeny informace, že jednou z oblastí, kterou př́íslušný výzkum pokrývá, je také fyzika, byl článek do analýzy zahrnut.

${ }^{4}$ Dostupné z http://www.scopus.com. Databáze SCOPUS byla zvolena mimo jiné z toho důvodu, že zahrnuje některé významné časopisy, např. Physics Education, Journal of Science Teacher Education, které v jiných databázích uvedeny nejsou.
} 
stránce, v sekci document search) bylo při vyhledávání těchto článků zvoleno physics education research, které bylo hledáno v abstraktech článků (zadáno article $\mathrm{v}$ sekci document type $)^{5}$. Výběr byl dále omezen na články psané anglickým jazykem.

Tento způsob vyhledávání článků má ovšem určité limity. Jedním z nich je, že jsou takto identifikovány články, které obsahují nejen zvolený klíčový termín physics education research jako celek, ale také články, kde jsou tato tři slova uvedena odděleně. Analýzou bylo zjištěno, že některé články z této druhé skupiny do PER patří, jiné ovšem nikoli. Relevantních se nakonec ukázalo celkem 146 článků. Především kvůli specifické volbě klíčového termínu je třeba absolutní četnosti článků (viz níže v kapitole 2) brát pouze jako dolní odhady skutečného počtu odpovídajících studií, a relativní četnosti jsou tudíž jen hrubým přiblížením zastoupení jednotlivých druhů článků a výzkumů. U nalezených článků byly z obsahového hlediska analyzovány jejich abstrakty, ve kterých byly hledány informace o metodách sběru dat. V abstraktech některých článků bohužel nebyly tyto informace (dostatečně podrobně) uvedeny, a tak se (pokud byly dostupné jejich plné verze) přikročilo k obsahové analýze plných textů článků. Zároveň bylo zaznamenáno, ve kterém časopisu byl článek publikován, příp. další informace, které se zdály relevantní (podrobněji v kapitole 2).

Limitem výše popsané metodologie zřejmě je, že se poměrně značně omezuje výběr textů. Při vyhledávání článků se nabízí volit např. klíčová slova physics teaching, physics learning atd. Dále tento přístup neumožňuje systematicky reflektovat příspěvky z konferencí a ani články z lokálních (národních) časopisů. Na druhou stranu lze tento přístup částečně obhájit tím, že mnohé kvalitní výstupy PER jsou mezinárodní komunitě $\mathrm{v}$ dovršené podobě často nabízeny právě v časopisech zařazených do databází (napřr. SCOPUS).

\section{VÝSLEDKY}

Ačkoliv je tato studie zaměřena na metody sběru dat, které jsou v rámci PER v mezinárodním prostředí využívané, objevily se během analýzy článků další informace, které můžeme považovat za přínosné. Níže tedy uvádíme i tato další zjištění, přičemž odpověd’ na výzkumnou otázku lze najít zejména v podkapitole 2.2.

\subsection{ANALYZOVANÉ ČASOPISY}

Informace o tom, které časopisy můžeme považovat za relevantní zdroje výzkumných studií v oblasti PER, může být podstatná jednak z hlediska vyhledávání dalších článků, jednak z hlediska možností publikovat výzkumy v rámci PER. Časopisů, ve kterých byly nalezeny články splňující kritéria popsaná výše (viz kapitola 1), bylo identifikováno sedmdesát. Vzhledem k jejich relativně velkému počtu uvádíme jejich seznam v př́loze (tabulka 6) na konci textu.

K časopisům, které se výrazně orientují na PER, patř́ zejména Physical Review Special Topics - Physics Education Research, následovaný periodiky International Journal of Science Education; American Journal of Physics; International Journal of Science and Mathematics Education a Research in Science Education. Mezi dalšími můžeme najít jak časopisy zaměřené úžeji na physics education (research), např. European Journal of Physics a Physics Education, tak časopisy se širším záběrem

\footnotetext{
${ }^{5} \mathrm{Na}$ webové stránce www.scopus.com bylo dále $\mathrm{v}$ rámci subject areas zvoleno physical sciences a social sciences $\&$ humanities.
} 
na science education (research), napr. Journal of Science Teacher Education nebo Science and Education. Některé z dalších časopisů jsou zaměřeny obecně na vzdělávání, např. Educational Studies a Evaluation and Research in Education. Výzkumné studie z oblasti PER však byly nalezeny i v časopisech, které jsou úžeji profilované mimo PER, např. Sex Roles; Journal of Women and Minorities in Science and Engineering a Curriculum Journal.

\subsection{METODY SBĚRU DAT}

\subsubsection{ZÁKLADNÍ PřEHLED}

V tabulce 1 jsou uvedeny metody sběru dat, které byly identifikovány v analyzovaných časopiseckých článcích.

Tab. 1: Metody sběru dat identifikované v analyzovaných časopiseckých článcích

\begin{tabular}{lcc}
\hline Metoda sběru dat & $\begin{array}{c}\text { Absolutní } \\
\text { četnost } \\
\text { článků }\end{array}$ & $\begin{array}{c}\text { Relativní } \\
\text { četnost } \\
\text { článků }\end{array}$ \\
\hline dotazník & 68 & $30 \%$ \\
interview & 59 & $26 \%$ \\
didaktický test & 52 & $23 \%$ \\
analýza dokumentů & 23 & $10 \%$ \\
pozorování & 20 & $9 \%$ \\
jiné & 5 & $2 \%$ \\
\hline celkem & 227 & $100 \%$ \\
\hline
\end{tabular}

Z tabulky 1 je zřejmé, že nejčastěji používanými metodami sběru dat jsou dotazník, interview a didaktický test. Dále je využivána analýza nejrůznějších dokumentů (podrobněji dále) a pozorování. Jen sporadicky byly použity jiné metody, které nelze jednoznačně zahrnout mezi předcházející (podrobněji níže).

Je zřejmé, že v některých výzkumech (příslušných článcích) bylo použito více metod sběru dat, protože ve 146 článcích bylo identifikováno celkem 227 metod. Rozdělení článků podle počtu metod sběru dat, které jsou v nich a v příslušných výzkumech použity, je uvedeno v tabulce $2 .{ }^{6}$

Tab. 2: Rozdělení časopiseckých článků podle počtu metod sběru dat

\begin{tabular}{lcc}
\hline $\begin{array}{c}\text { Počet metod } \\
\text { použitých v daném } \\
\text { článku (výzkumu) }\end{array}$ & $\begin{array}{c}\text { Absolutní } \\
\text { četnost } \\
\text { článků }\end{array}$ & $\begin{array}{c}\text { Relativní } \\
\text { četnost } \\
\text { článků }\end{array}$ \\
\hline jedna & 86 & $59 \%$ \\
dvě & 43 & $29 \%$ \\
tři & 13 & $9 \%$ \\
čtyři & 4 & $3 \%$ \\
\hline celkem & 146 & $100 \%$ \\
\hline
\end{tabular}

Z tabulky 2 je patrné, že ve více než polovině článků je použita jediná metoda sběru dat (přesněji: jediný druh - viz poznámka 6), v necelé třetině prací dvě metody a jen výjimečně tři a více metod sběru dat.

\footnotetext{
${ }^{6}$ Pokud jsou v daném článku (a výzkumu) použity např. dva didaktické testy, je tato metoda vykázána v tabulce 2 jen jednou. Přesněji lze říci, že v tabulce 2 jsou uvedeny počty různých druhů metod sběru dat (vymezených v tabulce 1 ).
} 


\subsubsection{DotaZník}

Dotazník představuje metodu sběru dat, která byla v analyzovaných studiích (a příslušných výzkumech) použivána nejčastěji. Identifikován byl v 68 případech, čemuž odpovídá téměř polovina všech článků (mezi metodami tvoří dotazník asi $30 \% \%^{7}$ ). Dotazníky představují poměrně širokou skupinu nástrojů a termínu dotazník odpovídají různé anglické ekvivalenty: questionnaire, survey, inventory. V tabulce 3 je uveden přehled některých dotazníků, které jsou v mezinárodním prostředí v rámci PER častěji používány.

Tab. 3: Dotazníky častěji používané v mezinárodním prostředí v rámci PER

\begin{tabular}{|c|c|c|}
\hline Název dotazníku & Zkratka & Př́ḱlady použití \\
\hline $\begin{array}{l}\text { The Colorado Learning Attitudes about } \\
\text { Science Survey for Experimental Physics }\end{array}$ & E-CLASS & Zwickl et al. (2014) \\
\hline The Five-Factor Personality Inventory & FFPI & Korpershoek et al. (2010) \\
\hline $\begin{array}{l}\text { The Maryland Physics Expectation } \\
\text { Survey }\end{array}$ & MPEX & $\begin{array}{l}\text { Sharma, Ahluwalia } \\
\text { \& Sharma (2013) }\end{array}$ \\
\hline $\begin{array}{l}\text { The Problem Solving Confidence } \\
\text { Questionnaire }\end{array}$ & PSCQ & Gok (2013) \\
\hline $\begin{array}{l}\text { Sources of Self-Efficacy in Science } \\
\text { Courses-Physics }\end{array}$ & SOSESC-P & $\begin{array}{l}\text { Sawtelle, Brewe } \\
\text { \& Kramer }(2012)\end{array}$ \\
\hline
\end{tabular}

Typické je, že se pomocí dotazníku zjištují postoje $\mathrm{k}$ fyzice, a to bud’ jako vědě (oboru lidské činnosti) nebo k vyučovacímu předmětu (zejména postoje k inovativní výuce). Dotazník využívají např. Zwickl et al. (2014), kteří se zabývají epistemologií a očekáváními studentů v souvislosti s jejich prací ve fyzikální laboratoři. Tato do značné míry metodologická studie seznamuje poměrně podrobně s výzkumným nástrojem E-CLASS (viz tabulka 3). Je inspirativní, že v rámci studie je detailně doložena a diskutována jeho validita (obsahová - content validity, konvergentní convergent validity). V př́loze studie jsou pak uvedeny položky dotazníku. Některé z dotazníků, např. FFPI (Korpershoek et al., 2010) sice samy o sobě nespadají do oblasti PER, ale jsou v rámci ní využívány. Poměrně časté je použití dotazníku a zároveň další metody sběru dat (např. interview) v rámci jednoho výzkumu.

\subsubsection{INTERVIEW}

Rozhovor (interview) je metodou sběru dat, která byla v analyzovaných výzkumech používána po dotazníku nejčastěji. Identifikováno bylo v 59 případech. Také interview (podobně jako dotazník) představuje poměrně širokou množinu nástrojů. Používány byly zejména polostrukturované rozhovory (semi-structured interview, např. Danielsson, 2012), individuální hloubkové rozhovory (individual in-depth interview, např. Choi, Nieminen \& Townson, 2012) a rozhovory vedené v rámci ohniskových skupin (focus groups interview/discussion, napr. Buck et al., 2014). Interview byla typicky kombinována s dalšími metodami sběru dat (zejména dotazníkem, didaktickým testem, dále pozorováním a analýzou dokumentů), a to zejména $\mathrm{v}$ rámci kvalitativně orientovaných a smíšených výzkumů.

\footnotetext{
${ }^{7}$ Tato relativní četnost je dána tím, že ve 146 analyzovaných článcích bylo identifikováno celkem 227 metod (tj. v mnoha výzkumech byly použity dvě, příp. více metod sběru dat). $\mathrm{V}$ tomto konkrétním př́ipadě je relativní četnost $68 / 227=0,30$.
} 


\subsubsection{DIDAKTICKÝ TEST}

Didaktické testy patři mezi poměrně hojně používané metody sběru dat v současném PER. Identifikovány byly v 52 př́ipadech. Mezi didaktickými testy zaujímají významné místo tzv. konceptuální testy (nazývané různě: concept(ual) test, concept(ual) inventory, concept(ual) survey), které se zaměřují na odhalování chybných prekoncepcí, zejména žáků (podrobněji v češtině Mandíková \& Trna, 2011: s. 9-16). V posledních desetiletích bylo v mezinárodním prostředí vyvinuto, ověřeno a použito větší množství konceptuálních, příp. dalších didaktických testů uvedených v tabulce 4 (dále Docktor \& Mestre, 2014).

Tab. 4: Konceptuální (a další významné didaktické) testy používané v mezinárodním prostředí

\begin{tabular}{|c|c|c|}
\hline Název testu & Zkratka & Příklady použití \\
\hline $\begin{array}{l}\text { The Astronomy Concept and } \\
\text { Achievement Test }\end{array}$ & ACAT & Kanli (2014) \\
\hline $\begin{array}{l}\text { The Basic Electricity and Magnetism } \\
\text { Assessment }\end{array}$ & BEMA & Thacker et al. (2014) \\
\hline The Certainty of Response Index & CRI & $\begin{array}{l}\text { Colclough, Lock \& Soares } \\
\text { (2011) }\end{array}$ \\
\hline $\begin{array}{l}\text { The Colorado Upper-Division } \\
\text { Electrostatics Assessment }\end{array}$ & CUE & Chasteen et al. (2012) \\
\hline $\begin{array}{l}\text { The Conceptual Survey of Electricity } \\
\text { and Magnetism }\end{array}$ & CSEM & Rudolph et al. (2014) \\
\hline $\begin{array}{l}\text { The Determining and Interpreting } \\
\text { Resistive Electric Circuits Concepts Test }\end{array}$ & DIRECT & Dzikovska et al. (2014) \\
\hline The Electric Circuit Diagnostic Test & ECDT & Dzikovska et al. (2014) \\
\hline $\begin{array}{l}\text { The Force and Motion Conceptual } \\
\text { Evaluation }\end{array}$ & FMCE & $\begin{array}{l}\text { Otero, Pollock \& Finkelstein } \\
(2010)\end{array}$ \\
\hline The Force Concept Inventory & FCI & Morris et al. (2012) \\
\hline $\begin{array}{l}\text { Lawson's Classroom Test of Scientific } \\
\text { Reasoning }\end{array}$ & CTSR & $\begin{array}{l}\text { Nieminen, Savinainen \& Viiri } \\
(2012)\end{array}$ \\
\hline $\begin{array}{l}\text { The Mechanical Waves Conceptual } \\
\text { Survey }\end{array}$ & MWCS & Tongchai et al. (2011) \\
\hline The Mechanics Base & MBT & t al. (2014) \\
\hline The Physics Achievement Test & PAT & Gok (2013) \\
\hline $\begin{array}{l}\text { The Test of Conceptual Understanding } \\
\text { of Newtonian Physics }\end{array}$ & TCUNP & Saleh (2012) \\
\hline The Thermodynamic Concept Survey & TCS & Wattanakasiwich et al. (2013) \\
\hline
\end{tabular}

Konceptuální testy zaměřující se na zkoumání pochopení určitých pro danou oblast typických pojmů nemusí být administrovány pouze žákům, ale mohou přinést také informaci o osvojení daných představ např. učiteli (Kanli, 2014). Mezi výše zmíněnými studiemi můžeme najít mimo jiné i ty, které se zabývají tvorbou nebo zkoumáním vlastností určitého konceptuálního testu (Wattanakasiwich et al., 2013; Morris et al., 2012). I když je zřejmé, že zkoumání žákovských prekoncepcí je silným tématem PER, přesto se objevují studie přicházející s určitými výhradami k takto pojatým výzkumům. Někteří badatelé tak např. doporučují spíše než prekoncepcemi zabývat se stavem, kdy žáci konceptuální porozumění prostě postrádají - mluví se o missing conceptions, viz von Aufschnaiter \& Rogge (2010). 


\subsubsection{ANALÝZA DOKUMENTU゚}

Rozbor různých dokumentů (záznamů) byl sice identifikován ve výrazně menším počtu studií (23), zahrnuje ale několik poměrně odlišných případů. Někteří autoři analyzovali např. emailovou komunikaci (Enderle, Southerland \& Grooms, 2013), jiní webové stránky (Crowl et al., 2013), další kurikulární dokumenty příslušných předmětů na daném stupni vzdělávání (Şardağ et al., 2014). V rámci jedné studie byly analyzovány dětské kresby (children's drawings), a to v souvislosti s havárí jaderné elektrárny v japonské Fukushimě (Neumann, 2014).

\subsubsection{Pozorování}

Poměrně málo použivanou metodou sběru dat bylo pozorování (observation). Bylo identifikováno ve 20 výzkumných studiích. Většinou se jednalo o pozorování a následnou analýzu s použitím videa (video study, video-based research). Např. Karam (2014: s. 4) využil software Videograph k analýze vybraných výukových epizod. Tento kvalitativně orientovaný výzkum, jehož výzkumným plánem byla př́padová studie, vedl k identifikaci souboru kategorií, které popisují různé strategie učitele vedoucí ke zdůraznění role matematiky ve výuce.

\subsubsection{JINÉ METODY SBĚRU DAT}

Jen sporadicky se $\mathrm{v}$ příslušných výzkumech objevily další metody sběru dat. Výjimkami jsou např. Simon \& Cuenca-Lorente (2012), kteří analyzovali v rámci své historické studie sbírky vědeckých, mimo jiné i fyzikálních pomůcek (analysis of scientific instrument collections), a Emdin (2011), který v rámci etnografického výzkumu sbíral data mimo jiné v podobě terénních poznámek (field notes).

\subsection{ORIENTACE VÝZKUMNÉHO PŘíSTUPU A VÝZKUMNÉ PLÁNY}

\subsubsection{ZÁKLADNÍ PřEHLED}

Tato část sice překračuje původně vymezenou výzkumnou otázku, nicméně informace o orientaci výzkumů a použitých výzkumných plánech můžeme považovat za vhodný doplněk přehledu metod sběru dat.

Při analýze se sice ukázalo, že autoři článků poměrně často v abstraktu nedeklarovali orientaci výzkumného přístupu, který využívali; někdy nebyla tato informace uvedena explicitně ani v části článku, která se zabývala použitými metodami, na druhou stranu na orientaci výzkumného př́istupu bylo možné usuzovat z analýzy použitých metod sběru dat a dále na základě způsobu vyhodnocování výsledků. V tabulce 5 je uvedeno rozdělení analyzovaných časopiseckých článků podle orientace výzkumného přístupu, který byl v přislušných výzkumech uplatněn.

Tab. 5: Rozdělení analyzovaných časopiseckých článků podle orientace výzkumného př́stupu

\begin{tabular}{lcc}
\hline Výzkumný přístup & $\begin{array}{c}\text { Absolutní } \\
\text { četnost } \\
\text { článků }\end{array}$ & $\begin{array}{c}\text { Relativní } \\
\text { četnost } \\
\text { článků }\end{array}$ \\
\hline kvalitativní & 44 & $30 \%$ \\
kvantitativní & 61 & $42 \%$ \\
smíšený & 41 & $28 \%$ \\
\hline celkem & 146 & $100 \%$ \\
\hline
\end{tabular}


Je zřejmé, že mezi zkoumanými publikacemi se poměrně často objevují jak články s kvantitativně orientovaným, tak i kvalitativně orientovaným výzkumem. Identifikovány byly také studie využívající smíšený přístup. V některých případech byla hranice např. mezi smíšeným a kvantitativním přístupem poměrně neostrá, protože kvantitativní část dominovala a bylo na zvážení, zda se přiklonit ještě ke kvantitativnímu přístupu nebo už ke smíšenému. Určitá převaha kvantitativního výzkumu není příliš výrazná. Pokud budeme velmi jednoduše předpokládat, že výzkumy se smíšeným přístupem jsou zhruba z poloviny tvořeny kvantitativním a z poloviny kvalitativním výzkumem, bude na kvantitativně orientovaný výzkum celkově připadat přibližně $56 \%$ a na kvalitativní zhruba $44 \%{ }^{8}$

Pro kvantitativní výzkum se ukazuje z hlediska metod sběru dat jako typické použití didaktických (konceptuálních) testů a dotazníků. Jako výzkumný plán se často uplatňuje porovnávání efektů dosažených u experimentální a kontrolní skupiny osob (např. Saleh, 2012; Eren \& Akinoglu, 2013; Kiliç \& Şen, 2014). V rámci kvalitativního výzkumu byla jako výzkumný plán používána zejména př́padová studie a omezeně také zakotvená teorie a etnografie (podrobněji část 2.3.2). Jako metody sběru dat se uplatňovaly hlavně interview a dotazníky, dále pak analýza dokumentů a pozorování.

Příkladem použití smíšeného výzkumného přístupu (mixed methods design) je studie dvojice autorů Markic a Eilks (2012). Cílem bylo poskytnout obrázek o představách studentů týkajících se vyučování a učení se přírodovědným oborům a to tak, že budou integrována data z různých zdrojů a ze studií, které jsou jak kvalitativní, tak kvantitativní povahy (Markic \& Eilks, 2012: s. 593). Tato studie zároveň překračuje oblast PER, protože jsou zkoumáni nejen budoucí učitelé fyziky, ale také studenti učitelství biologie a chemie. $\mathrm{K}$ analýze a pochopení studované problematiky se autoři rozhodli pro integrační model smíšeného přístupu (integrative model of mixed methods research). Ten se snaží integrovat data jednak během samotného procesu jejich sběru, ale také při jejich analýze a nakonec i při interpretaci.

\subsubsection{VYBRANÉ VÝZKUMNÉ PLÁNY}

\section{PŘÍPADOVÁ STUDIE}

Mezi výzkumnými plány používanými v rámci kvalitativního, příp. smíšeného výzkumu byla poměrně často využívána př́ipadová studie ( case study), která se typicky snaží zodpovědět výzkumnou otázku na základě podrobného popisu a rozboru jednoho nebo několika případi̊.

Jako př́iklad kvalitativního výzkumu, jehož výzkumným plánem je případová studie, můžeme uvést výzkum Danielssonové (2012). Jedná se o součást rozsáhlejšího výzkumného projektu, který má za cíl zkoumat, jak se konstituuje identita vysokoškolských studentek a studentů fyziky. Výzkumnice prováděla polostrukturované rozhovory, aby prozkoumala, co může znamenat být studentkou fyziky na univerzitě. Původně byly provedeny rozhovory s 12 vysokoškolačkami a 10 vysokoškoláky z jedné švédské univerzity, ale pro další účely byly použity rozhovory již jen s pěti ženami. Interview byla zvukově nahrávána a doslovně přepsána. Výzkum v podstatě sestává z pěti př́padových studií. Přes různé rozdíly mezi studentkami se ukazuje, že v některých ohledech jsou si podobné. Tomu odpovídá struktura článku v části

\footnotetext{
${ }^{8}$ Připomeňme, že vzhledem k metodologii použité při analýze článků je třeba zejména relativní četnosti brát jako velmi orientační. Relevantní je konstatování, že ke každému typu výzkumů (podle orientace výzkumného př́stupu) bylo nalezeno více než 40 článků.
} 
s výsledky; studentky Mia a Ann jsou označeny heslem „anomálie ženy ve fyzice“, Klara a Hanna zkratkou „stát se fyzičkou - nebo ne?" a Cecilia je označena jako „experimentátorka“. Na jedné straně je zřejmé, že použití kvalitativního př́istupu a pěti případových studií (jako výzkumného plánu) nemůže vést $\mathrm{k}$ výsledkům, které by bylo možné široce zobecnit, na druhou stranu takto pojatý výzkum může přinést hlubší vhled nejen do vybraných případů, ale zprostředkovaně do celého problému, jehož jsou součástí.

\section{ZAKOTVENÁ TEORIE}

K zakotvené teorii (grounded theory), která patří mezi výzkumné plány kvalitativního, př́íp. smíšeného výzkumu, odkazuje jen několik nalezených výzkumů (Markic \& Eilks, 2012; Kock et al., 2013). V rámci tohoto výzkumného plánu je snaha induktivně generovat teorii popisující a vysvětlující určitý fenomén (podrobněji např. Strauss \& Corbinová, 1999). S využitím zakotvené teorie byly zkoumány představy německých studentů učitelství přírodovědných předmětů týkající se vyučování a učení (Markic \& Eilks, 2012). Použití zakotvené teorie konkrétně vedlo k testování na třech škálách - zaměřených na představy o organizaci výuky ve třídě, představy o výukových cílech a epistemologické představy. Z výzkumu vyplynulo, že studenti učitelství fyziky (spolu s budoucími učiteli chemie) mají spíše tradiční představy o výuce, zatímco studenti učitelství biologie a budoucí učitelé na 1 . stupni ZŠ zastávají názory více spjaté s moderními vzdělávacími teoriemi.

\section{ETNOGRAFIE}

Pouze sporadicky byly využíiány prvky etnografie (ethnography) jakožto výzkumného plánu kvalitativně orientovaného výzkumu. Emdin (2011) zkoumá a dokumentuje komunikaci mladých lidí v oblasti přírodovědných oborů, kteří navštěvují městské školy (urban schools). Jako metody sběru dat při tom využil jak terénní poznámky (field notes), tak videonahrávky. Výzkumník se tak zabýval tématem, které je tradičně v oblasti PER poněkud přehlíženo. Jiný autor, Candela (2013), se zabýval specifiky vzdělávání v souvislosti s etnickou skupinou Tzeltalů (konkrétně tzeltalských učitelů, žijících na území Mexika).

\section{ZÁVĚR A DISKUZE}

Odpovědí na stanovenou výzkumnou otázku je, že metodami sběru dat, které jsou v mezinárodním prostředí v současné době v oblasti výzkumu fyzikálního vzdělávání využívány, jsou dotazník, interview a didaktický (zejména konceptuální) test. Dále je využívána analýza různých dokumentů (emailová komunikace, webové stránky, kurikulární dokumenty, dětské kresby), pozorování (s použitím videa) a sporadicky také jiné metody.

Podstatné je, že v mnoha analyzovaných studiích z mezinárodního prostředí byly identifikovány výzkumné nástroje, které jsou standardizovány. Jedná se zejména o různé konceptuální testy a dotazníky určené $\mathrm{k}$ měření postojů, příp. zjištující zpětnou vazbu z realizované výuky. Tyto nástroje jsou potenciálně využitelné také v domácím prostředí. Znalost jejich vlastností může pomoci při adekvátním převodu do jinojazyčné varianty, přestože i tak je velmi žádoucí shromáždit doklady o validitě a reliabilitě takto upraveného nástroje. 
V rámci diskuze výše uvedených zjištění se nabízí porovnat situaci v oblasti metodologie se stavem v České republice. Jednou možností by bylo porovnat celkovou produkci v mezinárodním prostředí s příspěvkem českých autorů v rámci ní. Pokud jde ale o databázi SCOPUS a výše zvolená kritéria výběru, texty českých autorů v ní nalezneme velmi sporadicky. Jinou možností je porovnání s českými studiemi uváděnými v domácích odborných časopisech (zejména v periodikách Scientia in educatione, Orbis scholae, Pedagogická orientace, Pedagogika, Matematika-fyzikainformatika, příp. dalších). Tento přístup je oprávněný, nicméně vzhledem $\mathrm{k}$ tomu, že by vydal zřejmě na samostatnou studii, zaměříme se na porovnání s českými pracemi, které v nedávné době byly z hlediska použité metodologie již analyzovány, a těmi jsou disertační práce (Žák, 2015).

V disertačních pracích z didaktiky fyziky obhájených v České republice v letech 2004 až 2013, resp. v př́śslušných výzkumech byl nejčastěji jako metoda sběru dat použiván dotazník a dále didaktický test, méně byla využívána analýza textů, učebnic, kurikulárních dokumentů, prací žáků, dále pozorování a interview (podrobněji Žák, 2015: s. 39-40). Určitý rozdíl je tedy patrný v tom, že zatímco v mezinárodním prostředí bylo interview využíváno poměrně často (byt jeho zjištěnou četnost je tř̌eba brát s rezervou), v českých disertačních pracích se jednalo o metodu používanou sporadicky. ${ }^{9}$

Provedená analýza přinesla také další důležité informace. Bylo zjištěno, že existuje poměrně velké množství časopisů (bylo jich nalezeno sedmdesát), ve kterých byly $\mathrm{v}$ posledních letech uveřejněny výzkumné studie spadající do oblasti PER (a které jsou zařazeny do databáze SCOPUS). Počet časopisů je třeba vnímat jako relativně velký (s důrazem na slovo relativně), protože je otázkou, kolik potenciálních autorů (z celého světa) existuje. Jako přínosná informace se jeví, že kromě časopisů, které se již podle názvu profilují jako časopisy zaměřené na physics (nebo science) education research, byly nalezeny mnohé další, kde je možné studie z PER publikovat, i když je zaměření těchto časopisů orientováno více či méně jinak.

Dále se ukazuje, že v mezinárodním prostředí v současné době v oblasti výzkumu fyzikálního vzdělávání jsou zastoupeny jak kvantitativně, tak kvalitativně orientované výzkumy a také výzkumy se smíšeným přístupem. Poměrně časté využivání kvalitativního přístupu $\mathrm{k}$ řešení výzkumných problémů PER můžeme chápat jako překvapivé, protože sám mateřský obor - fyzika je orientován výrazně kvantitativně (využívání náročného matematického aparátu).

Předložená analýza publikací není, jak bylo naznačeno již v úvodní části textu, z hlediska výběru relevantních textů úplná. V první řadě došlo k omezení díky tomu, že byla hledána určitá signifikantní slova (physics education research) v abstraktech článků. Je pravděpodobné, že ne u všech studií spadajících do PER se tato slova v textu abstraktu vyskytují. Tyto texty pak bohužel do analýzy zařazeny nebyly. Při volbě dalších klíčových slov je možné tuto analýzu doplnit a rozšśřit. Nicméně je zřejmě nemožné vygenerovat takovou množinu klíčových slov, aby problém s neúplností zcela odpadl.

Dále lze polemizovat s tím, že všechny časopisy zařazené do databáze SCOPUS (a v nich uveřejněné texty) vykazují vyšší kvalitu (co ji utváří?) než časopisy, které v ní zařazeny nejsou. Je třeba uvést, že vzhledem k procedurám, které podstupují články nabízené do odborných časopisů, zvláště těch uvedených v mezinárodních databázích, lze očekávat, že některé inovativní texty se publikování v těchto časopisech

\footnotetext{
${ }^{9}$ Málo časté používání interview (na rozdíl od velmi častého dotazníku) dokládá v současné době v didaktice chemie Rusek (2015: s. 23) a v didaktice biologie Pavlasová (2015: s. 8-9).
} 
nedočkají. To je další argument, proč nelze přehled o používané metodologii v této (a zřejmě ani jiné) oblasti zužovat na produkci již zavedených tradičních časopisů. V této souvislosti se může ukázat jako př́nosné zabývat se př́ispěvky, které jsou prezentovány také na konferencích. Ty totiž často nepodléhají tak striktním pravidlům (včetně konzervatismu) kladeným na jejich veřejnou prezentaci jako články časopisecké (s pozitivními i negativními důsledky). Stranou nemusí ovšem zůstat ani výzkumné studie uváděné v lokálních časopisech a prezentované na lokálních konferencích; pro řešení aktuálních lokálně podmíněných otázek mohou mít značný př́nos.

\section{LITERATURA}

Buck, G. A., Mills, M., Wang, J. \& Yin, X. (2014). Evaluating and exploring a professional conference for undergraduate women in physics: Can one weekend make a difference? Journal of Women and Minorities in Science and Engineering, 20(4), $359-377$.

Candela, A. (2013). Dialogue between cultures in Tzeltal teachers' cultural discourse: Co-construction of an intercultural proposal for science education. Journal of Multicultural Discourses, 8(2), 93-112.

Chasteen, S. V., Pollock, S. J., Pepper, R. E. \& Perkins, K. K. (2012). Thinking like a physicist: A multi-semester case study of junior-level electricity and magnetism. American Journal of Physics, 80(10), 923-930.

Choi, S. H.-J., Nieminen, T. A. \& Townson, P. (2012). Factors influencing international PhD students to study physics in Australia. Innovations in Education and Teaching International, 49(3), 309-318.

Colclough, N. D., Lock, R. \& Soares, A. (2011). Pre-service teachers' subject knowledge of and attitudes about radioactivity and ionising radiation. International Journal of Science Education, 33(3), 423-446.

Crowl, M., Devitt, A., Jansen, H., van Zee, E. H. \& Winograd, K. J. (2013). Encouraging prospective teachers to engage friends and family in exploring physical phenomena. Journal of Science Teacher Education, 24(1), 93-110.

Danielsson, A. T. (2012). Exploring woman university physics students 'doing gender' and 'doing physics'. Gender and Education, 24(1), 25-39.

Docktor, J. L. \& Mestre, J.P. (2014). Synthesis of discipline-based education research in physics. Physical Review Special Topics - Physics Education Research, 10(2), 1-58.

Dvořák, L., Kekule, M. \& Žák, V. (2012). Výzkum v oblasti fyzikálního vzdělávání - co, proč a jak. Čskoslovenský časopis pro fyziku, 62(5-6), 325-330.

Dvořák, L., Kekule, M. \& Žák, V. (2015). Didaktika fyziky včera, dnes a zítra. In I. Stuchlíková \& T. Janík (Eds.), Oborové didaktiky: vývoj - stav-perspektivy (123-157). Brno: Masarykova univerzita.

Dzikovska, M., Steinhauser, N., Farrow, E., Moore, J. \& Campbell, G. (2014).

BEETLE II: Deep natural language understanding and automatic feedback generation for intelligent tutoring in basic electricity and electronics. International Journal of Artificial Intelligence in Education, 24(3), 284-332.

Emdin, C. (2011). Dimensions of communication in urban science education: Interactions and transactions. Science Education, 95(1), 1-20. 
Enderle, P. J., Southerland, S. A. \& Grooms, J. A. (2013). Exploring the context of change: Understanding the kinetics of a studio physics implementation effort. Physical Review Special Topics - Physics Education Research, 9(1), 1-18.

Eren, C. D. \& Akinoglu, O. (2013). Effect of problem-based learning (PBL) on critical thinking disposition in science education. Journal of Environmental Protection and Ecology, 14(3A), 1353-1361.

Fenclová, J. (1982). Úvod do teorie a metodologie didaktiky fyziky. Praha: Státní pedagogické nakladatelství.

Fraser, J. B., McRobbie, C. J. \& Tobin, K. G. (Eds.). (2012). Second international handbook of science education. Dordrecht: Springer.

Gok, T. (2013). A comparison of students' performance, skill and confidence with peer instruction and formal education. Journal of Baltic Science Education, 12(6), 747-758.

Kanli, U. (2014). A study on identifying the misconceptions of pre-service and in-service teachers about basic astronomy concepts. Eurasia Journal of Mathematics, Science and Technology Education, 10(5), 471-479.

Karam, R. (2014). Framing the structural role of mathematics in physics lectures: A case study on electromagnetism. Physical Review Special Topics - Physics Education Research, 10(1), 1-23.

Kiliç, H. E. \& Şen, A. I. (2014). The effect of physics education based on out-of-school learning activities and critical thinking on students' attitudes. Eğitim ve Bilim, 39(176), $13-30$.

Kock, Z.-J., Taconis, R., Bolhuis, S. \& Gravemeijer, K. (2013). Some key issues in creating inquiry-based instructional practices that aim at the understanding of simple electric circuits. Research in Science Education, 43(2), 579-597.

Korpershoek, H., Kuyper, H., Werf, G. V. D. \& Bosker, R. (2010). Who 'fits' the science and technology profile? Personality differences in secondary education. Journal of Research in Personality, 44(5), 649-654.

Mandíková, D. \& Trna, J. (2011). Žákovské prekoncepce ve výuce fyziky. Brno: Paido.

Markic, S. \& Eilks, I. (2012). A comparison of student teachers' beliefs from four different science teaching domains using a mixed methods design. International Journal of Science Education, 34(4), 589-608.

Morris, G. A., Harshman, N., Branum-Martin, L., Mazur, E., Mzoughi, T. \& Baker, S. D. (2012). An item response curves analysis of the Force Concept Inventory. American Journal of Physics, 80(10), 923-930.

Neumann, S. (2014). What students think about (nuclear) radiation - before and after Fukushima. Nuclear Data Sheets, 120, 166-168.

Nezvalová, D. (2011). Didaktika fyziky v České republice: trendy, výzvy a perspektivy. Pedagogická orientace, 21(2), 171-192.

Nieminen, P., Savinainen, A. \& Viiri, J. (2012). Relations between representational consistency, conceptual understanding of the force concept, and scientific reasoning. Physical Review Special Topics - Physics Education Research, 8(1), 1-10.

Otero, V., Pollock, S. \& Finkelstein, N. (2010). A physics department's role in preparing physics teachers: The Colorado learning assistant model. American Journal of Physics, $78(11), 1218-1224$. 
Pavlasová, L. (2015). Disertační práce se zaměřením na didaktiku biologie v České republice v letech 2004-2013. Scientia in educatione, 6(2), 4-15.

Rudolph, A. L., Lamine, B., Joyce, M., Vignolles, H. \& Consiglio, D. (2014).

Introduction of interactive learning into French university physics classrooms. Physical Review Special Topics - Physics Education Research, 10(1), 1-18.

Rusek, M. (2015). Analýza disertačních prací z didaktiky chemie obhájených v letech 2003-2014. Scientia in educatione, 6(2), 16-34.

Saleh, S. (2012). The effectiveness of brain-based teaching approach in dealing with the problems of students' conceptual understanding and learning motivation towards physics. Educational Studies, 38(1), 19-29.

Şardă̆, M., Aydin, S., Kalender, N., Tortumlu, S., Çiftçi, M. \& Perihanoğlu, S. (2014). The integration of nature of science in the new secondary physics, chemistry and biology curricula. Eğitim ve Bilim, 39(174), 233-248.

Sawtelle, V., Brewe, E. \& Kramer, L. H. (2012). Exploring the relationship between self-efficacy and retention in introductory physics. Journal of Research in Science Teaching, 49(9), 1096-1121.

Sharma, S., Ahluwalia, P. K. \& Sharma, S. K. (2013). Students' epistemological beliefs, expectations, and learning physics: An international comparison. Physical Review Special Topics - Physics Education Research, 9(1), 1-13.

Simon, J. \& Cuenca-Lorente, M. (2012). Science education and the material culture of the nineteenth-century classroom: Physics and chemistry in Spanish secondary schools. Science and Education, 21(2), 227-244.

Strauss, A. \& Corbinová, J. (1999). Základy kvalitativního výzkumu. Boskovice: Albert.

Stuchlíková, I. \& Janík, T. (Eds.). (2011). Oborové didaktiky: bilance a perspektivy [Monotematické číslo]. Pedagogická orientace, 21(2).

Stuchlíková, I. \& Janík, T. et al. (2015). Oborové didaktiky: vývoj-stav-perspektivy. Brno: Masarykova univerzita.

Thacker, B., Dulli, H., Pattillo, D. \& West, K. (2014). Lessons from a large-scale assessment: Results from conceptual inventories. Physical Review Special Topics Physics Education Research, 10(2), 1-13.

Tongchai, A., Sharma, M. D., Johnston, I. D., Arayathanitkul, K. \& Soankwan, C. (2011). Consistency of students' conceptions of wave propagation: Findings from a conceptual survey in mechanical waves. Physical Review Special Topics - Physics Education Research, 7(2), 1-11.

von Aufschnaiter, C. \& Rogge, C. (2010). Misconceptions or missing conceptions? Eurasia Journal of Mathematics, Science and Technology Education, 6(1), 3-18.

Wattanakasiwich, P., Taleab, P., Sharma, M. D. \& Johnston, I. D. (2013). Development and implementation of a conceptual survey in thermodynamics. International Journal of Innovation in Science and Mathematics Education, 21(1), 29-53.

Zwickl, B. M., Hirokawa, T., Finkelstein, N. \& Lewandowski, H. J. (2014). Epistemology and expectations survey about experimental physics: Development and initial results. Physical Review Special Topics - Physics Education Research, 10(1), 1-14. 
Žák, V. (2014). Historický vývoj pojetí didaktiky fyziky v České republice. Pedagogická orientace, 24(2), 222-243.

Žák, V. (2015). Disertační práce z didaktiky fyziky obhájené v Ceské republice v letech 2004 až 2013 - přehled a analýza. Scientia in educatione, 6(2), 35-50.

VoJTĚCH ŽÁK, Vojtech.Zak@mff.cuni.cz

Univerzita Karlova, Matematicko-fyzikální fakulta

Katedra didaktiky fyziky

V Holešovičkách 2, 18000 Praha 8, Česká republika

\section{PřÍLOHA}

Tab. 6: Seznam časopisů, v nichž byly identifikovány články spadající do PER (časopisy jsou v první části tabulky uspořádány podle počtu analyzovaných článků - uveden v závorce za názvem časopisu; časopisy, ve kterých bylo identifikováno méně než pět článků, jsou uspořádány $\mathrm{v}$ druhé části tabulky již jen abecedně)

Název časopisu (počet relevantních článků)

Physical Review Special Topics - Physics Education Research (37)

International Journal of Science Education (12)

American Journal of Physics (7)

International Journal of Science and Mathematics Education (6)

Research in Science Education (6)

Asia-Pacific Forum on Science Learning and Teaching (5)

Eurasia Journal of Mathematics, Science and Technology Education (5)

Journal of Science Teacher Education (5)

Název časopisu (s méně než pěti relevantními články)

Advanced Science Letters

Alberta Journal of Educational Research

Asia-Pacific Education Researcher

Australasian Journal of Educational Technology

Australian Journal of Teacher Education

British Educational Research Journal

Canadian Journal of Physics

Canadian Journal of Science, Mathematics and Technology Education

CBE - Life Sciences Education

Cultural Studies of Science Education

Curriculum Journal

Developmental Psychology

Educational Studies

Egitim Arastirmalari - Eurasian Journal of Educational Research

Eğitim ve Bilim

E-Learning and Digital Media

Electronic Journal of e-Learning 
Emotion Review

Energy Education Science and Technology

European Journal of Engineering Education

European Journal of Physics

European Physical Journal: Special Topics

Evaluation and Research in Education

Gender and Education

Hacettepe Egitim Dergisi

Innovations in Education and Teaching International

International Education Studies

International Journal of Artificial Intelligence in Education

International Journal of Environmental and Science Education

International Journal of Game-Based Learning

International Journal of Innovation in Science and Mathematics Education

International Journal of Learning

Journal of Baltic Science Education

Journal of Chemical Education

Journal of Environmental Protection and Ecology

Journal of Multicultural Discourses

Journal of Research in Personality

Journal of Research in Science Teaching

Journal of Science Education

Journal of Science Education and Technology

Journal of Women and Minorities in Science and Engineering

Jurnal Teknologi (Sciences and Engineering)

Learning and Individual Differences

Middle East Journal of Scientific Research

New Educational Review

Nuclear Data Sheets

Pedagogische Studiën

Physica Medica

Physics Education

Research Journal of Applied Sciences

Revista de Educación

Revista Mexicana de Fúsica E

Romanian Reports in Physics

Science

Science and Education

Science Education

Sex Roles

Studies in Higher Education

Teaching and Teacher Education

Teaching Mathematics and its Applications

Theoretical Issues in Ergonomics Science

World Applied Sciences Journal 